\section{Karyotyping and} population genetics in Cold War Mexico: Armendares's and Lisker's characterization of child and indigenous populations, 1960s-1980s

\author{
Cariotipia e genética de \\ populações no México da
}

Guerra Fria: as caracterizações de Armendares e Lisker sobre as populações infantil e indígena, 1960-1980

\author{
Ana Barahona \\ Professor, Department of Evolutionary Biology/ \\ Universidad Nacional Autónoma de Mexico. \\ Coyoacán - Mexico City - Mexico \\ orcid.org/0000-0001-7765-6444 \\ ana.barahona@ciencias.unam.mx
}

Received on 2 Feb. 2018.

Approved on 10 Oct. 2018.

http://dx.doi.org/10.1590/S0104-59702019000100014
BARAHONA, Ana. Karyotyping and population genetics in Cold War Mexico: Armendares's and Lisker's characterization of child and indigenous populations, 1960s-1980s. História, Ciências, Saúde - Manguinhos, Rio de Janeiro, v.26, n.1, jan.-mar. 2019, p.245264.

Abstract

This paper focuses on geneticists Salvador Armendares's and Rubén Lisker's studies from the 1960s to the 1980s, to explore how their work fits into the post-1945 human biological studies, and also how the populations they studied, child and indigenous, can be considered laboratories of knowledge production. This paper describes how populations were considered for different purposes: scientific inquiry, standardization of medical practices, and production or application of medicines. Through the narrative of the different trajectories and collaborations between Armendares and Lisker, this paper also attempts to show the contact of their scientific practices, which brought cytogenetics and population genetics together at the local and global levels from a transnational perspective.

Keywords: Salvador Armendares (19252010); Rubén Lisker (1931-2015); population genetics; G6PD deficiency; lactase deficiency.

\section{Resumo}

Aborda o trabalho dos geneticistas Salvador Armendares e Rubén Lisker, entre 1960 e 1980, para analisar como se insere nos estudos biológicos humanos do pós-1945, e demonstra como as populações estudadas por eles, a infantil e a indígena, podem ser consideradas laboratórios de produção de conhecimento. $O$ artigo revela como as populações foram consideradas para diversos propósitos: investigação científica, padronização das práticas médicas e produção ou aplicação de suas medicinas. Por meio da narrativa das diferentes trajetórias e colaborações entre Armendares e Lisker, também procura discutir o contato de suas práticas científicas, que colocaram a citogenética e a genética de populações lado a lado nos níveis local e global a partir de uma perspectiva transnacional.

Palavras-chave: Salvador Armendares (1925-2010); Rubén Lisker (1931-2015); genética de populações; deficiência G6PD; deficiência de lactase. 
$\mathbf{I}_{\mathrm{ar}}^{\mathrm{n}}$ the summer of 1966, Mexican physicians-turned-geneticists Salvador Armendares and Rubén Lisker met through the physician Mario Salazar Mallén, who was a common acquaintance and Lisker's former teacher. From the 1960s to the 1980s, Armendares and Lisker made groundbreaking contributions to human genetics, particularly medical and human genetics. After spending two years at the British Medical Research Council in Oxford under the supervision of the British physician Alan C. Stevenson in 1964 and 1965, Armendares founded the first Unit for Research in Human Genetics (Unidad de Investigación en Genética Humana), at the Mexican Institute of Social Security (Instituto Mexicano del Seguro Social, IMSS), in 1966, while one year later Lisker founded the Genetics Department of the Nutrition Illnesses Hospital (Hospital de Enfermedades de la Nutrición) of the Ministry of Health and Public Assistance, after having collaborated with the GermanJewish physician Arno G. Motulsky in Seattle from 1965 to 1966. Their long-term research projects and different trajectories were connected at a time when Mexican researchers were consolidating the emerging model of human genetics that had been reconfigured after World War II on an international level. Both were part of international collaborative networks and were recognized as key actors in the rising field of human genetics in Mexico, Armendares focusing on the study of congenital malformations in children, and Lisker on hematological diseases in indigenous populations. Later on, both were pioneers in the emerging fields of bioethics and genetic counselling in Mexico.

Their entangled histories allowed them to bring cytogenetics and population genetics together, and to give human genetics its social life: Lisker and Armendares drove forward the creation of the Mexican Association of Human Genetics (Asociación Mexicana de Genética Humana, AMGH) in 1968, and organized and participated in numerous national and international conferences.

In this paper I focus on Armendares's and Lisker's studies from the 1960s to the 1980s to explore how their work fits in the larger tapestry of post-1945 human biological studies, and also how the populations they studied - children and indigenous peoples - can be considered laboratories for knowledge production (Lock, Nguyen, 2010) or sites of cognition (Anderson, 2012). ${ }^{1}$ The way in which biomedicine, a clear product of World War II, became the dominant medical system globally, turning human populations into perfect laboratories for the production of medical knowledge. Not only is "the knowledge acquired from these experimental sites... put to work in producing medications, the bulk of which may be consumed far from these experimental sites," but it also allows the standardization of clinical and scientific practices (Lock, Nguyen, 2010, p.13; see Barahona, 2015). Following Lock and Nguyen, I will describe in this paper how populations were considered the result of the way in which clusters of people were formally defined by nation-states, local governments, or research programs. These populations are specific entities for different purposes: scientific inquiry, standardization of medical practices, or the production or application of medicines. These targeted groups of people "exert agency and actively engage with biomedical interventions that are made available to them in order to bring about their own objectives" (Lock, Nguyen, 2010, p.113; see Hacking, 1986). ${ }^{2}$

I will try to show how Armendares and Lisker "transformed a physical area into a conceptual laboratory, invented as a site of testing" (MacLeod, Rehbock, 1994, p.4; see 
Anderson, 2012). Armendares's two-way-traffic between the hospital where the samples were taken and the laboratory where they were analyzed, and Lisker's back-and-forth travels to the indigenous locations to take the blood samples later analyzed in the laboratory, in fact configured sites of scientific inquiry, in which diagnostic and research activities were intertwined and became "vehicles for challenging nature as much as a means of analyzing the experiments" (Anderson, 2012, p.246, 2008). As the historian of science Susan Lindee (2014, p.185) puts it, "in the decades after the bomb, scientists collected and transferred human biological material and information from populations of interest, and as they moved these biological resources or biosocial resources acquired new meaning and uses" (see also Radin, 2017). ${ }^{3}$ Armendares's and Lisker's populations became the perfect laboratories for the study of congenital malformations and human variability.

The story I want to tell in this manuscript brings the history of human genetics in Mexico in contact with recent transnational studies that acknowledge cross-border interactions and the circulation of knowledge and scientific practices (Turchetti, Herrán, Boudia, 2012; Barahona, 2018). ${ }^{4}$ Through the narrative of the different trajectories and future collaborations between Armendares and Lisker, this paper also attempts to show the contact of their scientific practices, which brought cytogenetics and population genetics together.

The narrative is divided into three sections. The first part addresses Lisker's genetic characterization of indigenous populations, the second part focuses on Armendares's introduction of karyotyping techniques to study Down syndrome and child malnutrition, among other disorders, and the final part addresses their long-lasting collaboration and the founding of the AMGH in the pursuit of their shared personal agendas, taking into account international and global concerns about the effects of radiation on human populations and human health, and the measurement of human variability.

\section{Genetic characterization of indigenous populations and the work of Rubén Lisker}

Studies on the population structure and ancestry of human populations became important after 1945 in part due to the intersection of medicine and biology (particularly genetics and evolution), which gave rise to the field of biomedicine. This new field bolstered the circulation of knowledge in collaborative networks, which cannot be understood without paying attention to the incorporation of scientific practices into the historical trajectories of the locales in which they arrive (Lock, Nguyen, 2010). The globalization of biomedicine after World War II dissolved borders, and boundaries became spaces of scientific inquiry.

The end of Second World War changed the social organization of research (De Chadarevian, 2013; Lindee, 2005, 2015), and Mexico was no exception to this trend. It was in the 1940s that some studies on the genetic characterization of human populations began to appear. These studies gave a new understanding of the transmission of pathologies with a strong population component, and paved the way for the development and consolidation of human genetics in Mexico.

The first physician to conduct this kind of investigation was New York-educated Mario Salazar Mallén (1913-1976), who is considered a pioneer in the study of the distribution of 
blood groups in Mexico, particularly in indigenous and mixed-race populations (Salazar Mallén, Hernández de la Portilla, 1944), and of the inheritance of the Diego blood group. ${ }^{5}$ Results from the latter appeared in the journal Science, considering his contributions at the forefront of the field (Salazar Mallén, Arias, 1959). Salazar Mallén wanted to understand the inheritance and distribution of certain pathologies in relation to immunological diseases, being aware of New York physician Alexander Wiener's works on the distribution of human blood groups around the world (Salazar Mallén, 1949; Arteaga et al., 1952; see also Barahona, 2009, 2016b). ${ }^{6}$

These works were followed by other research groups, one led by Salazar Mallén's former student Rubén Lisker, with an emphasis on genetic markers in population genetics, and another led by Salvador Armendares, with an emphasis on cytogenetics.

After graduating from the School of Medicine at the National Autonomous University of Medico (Universidad Nacional Autónoma de México, UNAM), where he took courses in the history of medicine and therapeutics offered by Salazar Mallén, the US-born Mexican physician Rubén Lisker Yourkowitzy (1931-2015) decided to go to the Michael Reese Hospital in Chicago, Illinois, from 1954 to 1957. There, he specialized in hematology with the Viennese physician Karl Singer, a specialist in human hemoglobin. While there, Lisker became acquainted with Motulsky, who had been a pupil of Singer's a few years before. ${ }^{7}$

Lisker returned to Mexico to work for several years at the Nutrition Illnesses Hospital, then in 1965 he left for Seattle to work with Motulsky, who had moved there in 1953 to set up a Medical Genetics Division at the University of Washington, which began operations in 1957. At the time, Motulsky was researching G6PD (glucose-6-phosphate-dehydrogenase) deficiency, a genetic disorder behind the most common enzymatic deficiency in the world, characterized by premature hemolysis, causing anemia or the disease known as favism (after the fava bean). Upon his return to Mexico in 1967, Lisker founded the Department of Genetics at the Nutrition Illnesses Hospital, becoming its first director and inaugurating one of the most successful programs on the study of Mexican indigenous populations (Barahona, 2009). ${ }^{8}$

Two lines of research in population genetics were developed in the Department of Genetics in the 1960s, 1970s, and 1980s. One was related to the genetic characterization of various indigenous and mestizo groups through the use of genetic markers, and the other was related to adult-type lactase intestinal deficiency. The first line allowed the understanding of the genetic structure of the Mexican population and the identification of hemoglobin variants in diverse populations, while the second line gave a new perspective on the inheritance of the deficiency and its importance in the capacity and habit of milk consumption (Lisker, 1981, 1984; Barahona, 2009).

Research on human populations in Mexico was not only of anthropological importance, but also had a clear medical application: the design of medical policies specific to the populations that experienced higher rates of anemia and malaria (Barahona, 2009, 2016b). ${ }^{9}$ Mexican indigenous populations were experimental sites for producing health policies and standardizing scientific and clinical practices, and also for testing hypotheses about the historical interactions between different populations, showing a clear intersection of the development of post-Second World War biomedicine and the political project of 
post-revolutionary Mexico (see Cueto, 2007, 2015; for Armendares and post-revolutionary Mexico, see Barahona, 2015).

Influenced by Motulsky's work, Lisker's hematological studies of genetic markers, ${ }^{10}$ such as G6PD deficiency, were intended to provide information on hemolytic anemia in mestizo and indigenous groups, as Carson and colleagues had established in 1956 (Carson et al., 1956; see Motulsky, Campbell-Kraut, 1961). To conduct these studies, Lisker used (for the first time in Mexico) the linguistic classification of American cultural anthropologist Morris Swadesh, a former student of Boas's, who was working at UNAM at the time. The idea was to correlate linguistic similarities among populations with genetic similarities, as hemoglobin variants had well-defined geographical and ethnic distributions. ${ }^{11}$ Considering these populations as laboratories of knowledge production and sites of cognition, Lisker thought that this information could be used for medical purposes and also for testing hypotheses about the historical interactions between different populations. His main studies were on G6DP deficiency and human serum albumin, the most abundant protein in blood plasma (see Barahona, 2016a, 2016b).

Lisker conducted his research on indigenous populations by taking samples at indigenous locations and analyzing them in the laboratory using up-to-date techniques, such as starch gel electrophoresis, which allowed for finer molecular separation (Lisker et al., 1962; Rodríguez et al., 1963; Lisker, Loria, Córdova, 1965). With the help of the National Indigenous Institute (Instituto Nacional Indigenista) and the Summer Language School (Escuela Linguística de Verano), which had the infrastructure to take the blood samples and to manage the indigenous populations, Lisker and his colleagues made an extensive survey of the Mixtec linguistic area, which comprises the states of Puebla, Oaxaca, and Guerrero, in southern Mexico, where Lisker found a close relationship between the presence of G6PD deficiency and malaria. It was well known at the time that G6PD deficiency, like anemia and thalassemia, was a biochemical-genetic response to malaria discovered in the 1920s among workers in South American banana plantations run by the United Fruit Company (Comfort, 2012). Thanks to the National Campaign for the Eradication of Malaria, the Ministry of Health decided to study the area for G6PD deficiency as a preliminary step prior to implementing general treatment with primaquine (Barahona, 2009). In a population of 1,931 adult men, Lisker used hemoglobin S (HbS) and G6PD as genetic markers. After the genetic analyses, Lisker concluded that, despite the uniform incidence of malaria in the area in the recent past, there were marked differences in the frequency of both characteristics in neighboring cities. Later on, Lisker and his colleagues studied the distribution of abnormal hemoglobin and G6PD deficiency in two thousand Mexican Indians. After the samples were analyzed in the laboratory, the authors concluded that the frequency of G6PD deficiency was low and directly related to black admixture (Lisker, Zárate, Loría, 1966). Years later, Lisker and Motulsky described this as a new variant called "G6PD Mexico," which was the first to be reported among Amerindian populations and did not appear to have been introduced from other populations (Lisker et al., 1972).

Lisker did not stop using hemoglobin S (HbS) and G6PD as genetic markers until 1980 (see, for example, Lisker, Pérez-Briceño, Beutler, 1985). These studies linked urban and rural settings and linguistic and cultural approaches to the study of human biological 
diversity. In this way, Lisker's fieldwork techniques combined social, cultural, and historical knowledge of the research populations (Barahona, 2016a). ${ }^{12}$

Regarding the other line of research carried on at the Department of Genetics, it was known that lactase intestinal enzyme breaks down lactose, the complex sugar in milk, into the simple sugars glucose and galactose, in order to be absorbed. It was also known that mammals, including humans, are born with adequate levels of this enzyme in the intestine, but after two years its activity begins to decrease until most humans only retain $10 \%$. In order to investigate the genetic configuration of the populations in Mexico, Lisker and colleagues studied 61 families with 177 children over 6 years of age, constituting this population as a site of scientific inquiry and for the production and application of medicines (Lock, Nguyen, 2010). The prerequisites for inclusion in the study were that both parents should take part and that they must have at least one child aged 6 or older. The lactose tolerance test was performed after an overnight fast. Capillary samples were taken from participants after they had been given a dose of $2 \mathrm{~g}$ lactose per $\mathrm{kg}$ of body weight dissolved in water, in order to estimate blood glucose before and 15minutes after lactose intake. The results suggested that this deficiency was inherited as a simple Mendelian recessive trait, ${ }^{13}$ and that $70 \%$ of Mexicans did not have lactase after 6 years of age. These findings were very important because the studies were performed in an ethnic group in a rural area near Mexico City, where lactose intolerance was frequent (Lisker et al., 1974; Lisker, González, Daltabuit, 1975). Trying to find a solution for this deficiency in adults, Lisker and colleagues tested the addition of microbial $\beta$-galactosidase directly to milk as a potential enzyme replacement therapy. They studied 25 subjects with incomplete carbohydrate absorption with whole milk, adding the enzyme 5 minutes before consumption. This action reduced the symptoms of lactose intolerance by 62\% (Lisker, Aguilar, Zavala, 1978; Lisker, 1984; Rosado et al., 1984).

For Lisker, these investigations were important in the field of public health, because including milk as a nutritional supplement would be a risk to approximately $14 \%$ of the population, who would have symptoms of intolerance when ingesting it at the usual doses. It was conclusive that intestinal lactase deficiency was clinically relevant and that it should be considered when nutritional supplementation with milk was contemplated. Lisker was considering the studied populations as laboratories or sites for analytical scrutiny and he targeted populations to study lactase deficiency.

According to Jenny Reardon (2005, p.54), in the 1950s,

all geneticists still subscribed to the notion that visible physical traits corresponded to underlying genetic characteristics.... However, as molecular techniques and molecular biology developed in the 1960s, the meaning of the visible and the physical for the geneticist simultaneously changed. Using gel electrophoresis, geneticists could now observe not just... the surface of the body, but also molecules within the body's cellular structures. These molecules were held to be closer to the action of the genes, and thus better markers of their biological reality.

Like other geneticists of his generation, Lisker studied gene frequencies in indigenous populations, "not as a way to supersede studies of race, but rather as a way to study the 
formation of races in a manner that avoided the practical difficulties created by the modern mixing of subgroups of the human species" (Reardon, 2005, p.72).${ }^{14}$ In his 1981 book, Lisker insisted on the medical importance of the genetic characterization of Mexican populations and documented numerous studies that included all the work done by him and his work group and by other Mexican and foreign groups.

The work of Lisker and collaborators from the 1960s to the 1980s promoted the consolidation of medical and human genetic knowledge in Mexico and led to his group being considered a leader in the genetics of human populations. ${ }^{15}$ He also made important contributions to the area of human cytogenetics in collaboration mainly with Armendares, whose work will be discussed below.

\section{Karyotyping and the work of Salvador Armendares}

In the 1950s, human chromosome research was a field of inquiry that could link suffering with genetics by finding "new chromosome diseases," including sex chromosome abnormalities (Lindee, 1994; De Chadarevian, 2015). The study of the size and shape of each of the chromosomes (the practice of karyotyping) as an experimental method of analysis with clinical repercussions enabled the development of cytogenetics as a field of human genetics, specifically medical genetics, at a clear intersection of the postwar international agenda (De Chadarevian, 2013).

After the Second World War, karyotyping facilitated the introduction of heredity and genetics to clinical practice. The early days of human cytogenetics (from the 1950s to the 1970s) clearly show a culture of laboratory practices in which images and blood and bone marrow samples were circulated and the human body was biomedicalized, thus placing the live born and the unborn at the heart of medical genetics (Santesmases, 2017). Also, human cytogenetics "had transformed from a niche research area to a worldwide practice, thanks in large part to its clinical application in diagnosing Down syndrome and other chromosomal disorders" (Hogan, 2016, p.42).

As we will see, karyotyping was used as a diagnostic tool (Stern, 2012; De Chadarevian, 2014, 2015; Santesmases, 2014, 2015; Ha, 2015) ${ }^{16}$ to tackle children's health problems by means of targeting child populations as laboratories for knowledge production and hypothesis testing, becoming part of the emerging model of biomedicine.

In Mexico, two events were crucial to the development of cytogenetics in clinical practice. One was the creation, in 1966, of the Department of Scientific Research at the IMSS, funded by a million-dollar donation from the Ford Foundation, where the first Human Genetics Research Unit was to be established. The second was British human geneticist Alan C. Stevenson's visit to Mexico.

Although medical research was not one of the objectives behind the founding of the IMSS in 1943, it was in the 1960s, when growing interest in extending the services the institute provided for research arose within the Mexican medical community. The incorporation of young physicians that had studied abroad and had made great contributions to the field of medicine and human biology made it evident that research was essential to address population growth and child malnutrition, two of the main concerns of post-revolutionary 
Mexican governments (Barahona, 2015). One of the most conspicuous was Germanborn Mexican physician Silvestre Frenk Freund (1923-), best known for his contributions to the study of child malnutrition. After a sojourn in Germany, he returned to Mexico in 1956 to work at the Mexican Children's Hospital (Hospital Infantil), where he created the Endocrinology Department. He collaborated with Professor Jack Metcoff at the Children's Hospital in Boston, USA, where he discovered a procedure for producing nephrotic syndrome in rats (Frenk et al., 1955) and investigated the effect of severe malnutrition on renal tissue loss (Metcoff et al., 1957). Frenk left the Mexican Children's Hospital in 1963 in order to help set up the Pediatric Hospital of the IMSS National Medical Center (Centro Médico Nacional, CMN), where he was appointed head of the Endocrinology and Nutrition Department. It was here that Armendares began his career, thanks in part to Frenk's support and collaboration. ${ }^{17}$

Spanish-born Mexican physician Salvador Armendares (1925-2010) graduated from the School of Medicine at UNAM and worked as a pediatrician and researcher at both the CMN Gynecology and Obstetrics Hospital 2 and the CMN Pediatrics Hospital. It was here that he met Stevenson, when the latter was presenting an international prospective study on congenital malformations at the UNAM School of Medicine. With Frenk's support and a scholarship from UNAM, Armendares undertook graduate studies in human genetics in 1964 and 1965 at the British Medical Research Council in Oxford under Stevenson's supervision. ${ }^{18}$ At the time, the UK Medical Research Council's two main units concerned with radiation, in Edinburgh and Harwell, provided "a good example of how radiation related research benefited human genetics as a whole, by helping to develop new techniques such as the analysis of human chromosomes, and also by their foresight in supporting work which might have seemed beyond their remit, such as studies of Down's syndrome and of sex chromosome abnormalities" (Harper, 2018, p.10). Those years out of the country were of great importance not only for learning how to tackle the study of child populations from a genetic point of view, but also for learning novel techniques for understanding genetic and chromosomal variation.

In April 1959, American human geneticist James V. Neel, American population geneticist and epidemiologist William J. Schull, British human geneticist J.A. Fraser Roberts, and Stevenson met at Neel's Department of Human Genetics at the University of Michigan (the first in the United States) to implement a prospective study on the malformations occurring in consecutive births in hospitals in several countries. This study had been conceived in 1958 by the World Health Organization as a step towards understanding the occurrence and types of congenital malformations in live born and stillborn children in the international context about the effects of radiation on human populations (Stevenson et al., 1966). The four researchers agreed that Stevenson would carry out the study.

Mexico was one of the 15 countries chosen for the survey. The collecting of information began in 1961 and ended in 1964. The malformations recorded included the harelip and cleft palate, malformations of the gut and urogenital tract, and Down syndrome (Barahona, 2015). According to the study, in Mexico there was a relatively high frequency of Down syndrome: over one in every five hundred births. The study also showed that in Mexico City, the proportion of all pre-28th week losses that occurred between the 17th and 27th 
weeks was much higher than elsewhere, indicating that further analysis of the collected information might serve to identify the characteristics of a high-risk group of mothers and give clues to the etiology of the genetic condition (Stevenson et al., 1966).

As we have seen, upon Armendares's return from Oxford, he founded the first Unit for Research in Human Genetics at the Pediatrics Hospital, where he held the initial directorship, from 1966 to 1976. It was first located in a small room in Frenk's laboratory and consisted of Armendares and two technicians, but in 1968 it moved to its own laboratory in an adjoining area of the hospital, more personnel were hired, and more equipment was acquired (Barahona, 2015).

Influenced by the research work he had undertaken at Oxford with Stevenson, and due to the need to provide health services for the general population in post-revolutionary Mexican health institutions, the genetic research agenda of Armendares's group included the population genetics of congenital illnesses and particular disorders, such as child malnutrition, causes of chromosomal alterations, Down syndrome, mental retardation, and Turner syndrome, configuring child populations as sites for knowledge production (Armendares, Buentello, Salamanca, 1971; Salamanca, Buentello, Armendares, 1972).

Having learnt the lymphocyte culture techniques for chromosome analysis in Oxford (after Moorhead et al., 1960), Armendares was able to perform good cytogenetic observations. Along with his close collaborator and erstwhile student physician Leonor Buentello (1940-), he supervised blood sampling to ensure the correct identification of the subjects and the monitoring of the patients, whose parents had given their written authorization to use the material for investigation. The two men also performed tissue cultures and karyotyping of patients with Down syndrome and other disorders identified in patients at the hospital.

For the study on malnourished children, Armendares and Frenk, along with former student Fabio Salamanca (1940-), embarked on a longitudinal study of chromosome structure in five infants and five preschool children aged 1-60 months with advanced malnutrition. They obtained leucocyte cultures from peripheral blood from the patients on the day of admission to hospital and after 15, 20, 30, 40, and up to 140 days, using a standardized technique developed years before in the United States (Moorhead et al., 1960). ${ }^{19}$ They also obtained bone marrow samples of six malnourished children taken through sternal or iliac puncture by specialized nurses. They analyzed 2,940 samples at mitosis and reported a large number of chromosome abnormalities. Their results were published in the authoritative journal Nature (Armendares, Salamanca, Frenk, 1971, 1974). After this study, Armendares continued to work with Frenk in histopathological studies of bilateral cryptorchidism (Armendares, Buentello, Frenk, 1973).

Regarding the high frequency of Down syndrome, Turner Syndrome, and other chromosome abnormalities in Mexico, Armendares and his group performed the same protocol as for the other studies: they targeted the population of children at the hospital, obtained blood samples, and analyzed them in the laboratory. For Down and Turner syndrome, for example, they found a correlation between clinical observations and cytogenetic analysis, giving a chromosomal explanation of the syndromes (Armendares, Urrusti, Ramírez, 1968; see Barahona, 2015; Hogan, 2016). 
Armendares and his colleagues at the unit were convinced of the greater importance of chromosome studies in clinical practice, and argued that many human diseases were genetic phenomena that could be subject to technological control in hospital and laboratory practice. Armendares and his group realized that genetic disorders of childhood and congenital malformations were replacing infectious and nutritional diseases as the main causes of childhood mortality (Harper, 2018).

The populations involved were considered sites of knowledge inquiry (or sites of cognition), as data were collected, samples analyzed, and the results compared with other laboratories around the world, which circulated in international journals. In this way, knowledge was produced in a two-way-traffic from the hospital to the laboratory and from the bench to the bed. As Lindee (2005) illustrated for the United States, knowledge on genetic diseases in Mexico was produced in a "feedback loop of politics, theory, laboratory techniques, human suffering, and historical contingency." Or, as Hogan (2016, p.28) has put it, "the identification of a pattern of bodily malformations went hand-in-hand with the laboratory recognition that its associated chromosomal marker was in fact a mutation... The hybrid work of these postwar medical genetics subspecialties aimed to construct the life histories of many genetic diseases, with the hope of facilitating targeted prenatal prevention."

\section{Entangled histories and the social life of human genetics}

Armendares and Lisker met in the summer of 1966 thanks to a common acquaintance, Lisker's former teacher Salazar Mallén. From that moment on, they initiated a collaboration that put their respective disciplines into contact by combining the cytogenetic studies carried on atthe Unit for Research in Human Genetics with the population studies that Lisker was doing at the Nutrition Illnesses Hospital. ${ }^{20}$ Three events conspired to strengthen this collaboration: studies on the population genetics of certain chromosomal conditions, the creation of the AMGH, and the organization of national and international congresses; all of them concomitant in time and space.

In the 1960s, little was known about the localization of genes in specific human chromosomes. There was speculation that the G6PD system was located in chromosome 21 (Fialkow et al., 1969; Pantelakis et al., 1970). From these studies Armendares's and Lisker's groups designed an experimental approach to measure erythrocyte G6PD levels in children with Down syndrome, and the segregation of the electrophoretic variants of the enzyme in families with Down syndrome individuals. Blood samples were obtained from every mother accompanying her child to a specialized outpatient clinic. Down syndrome diagnosis was made on clinical grounds and corroborated by peripheral blood karyotype analysis, while G6PD levels were determined using the final concentration of the reagents. The phenotypic variants of the enzymes were depicted in a starch gel electrophoretic system following the technique developed by Bowman and colleagues (Bowman et al., 1966). A total of 93 mothers of Down syndrome patients were investigated, and 32 patients with Down syndrome were measured for G6PD. The final results did not support the suggestion of previous works that the G6PD gene was located in chromosome 21 (Lisker et al., 1971). 
The same kind of collaboration regarding the frequency of sister chromatid exchanges in severe protein calorie malnutrition were conducted by Lisker and Armendares's teams. The findings of the study were compatible with those of Armendares and colleagues in 1971 (Mutchinick et al., 1979).

In 1969, at the same time as these collaborations were taking place, Armendares started a medical genetics graduate program within the CMN Pediatrics Hospital, endorsed at the time by the graduate division of the UNAM School of Medicine. Armendares invited Lisker to join him in this new endeavor, asking him to deliver the population genetics courses. ${ }^{21}$ The syllabus included the biological bases for heredity, cellular biology, development biology, cytogenetics, clinical genetics, and human population genetics. The discipline was consolidated in 1988 with the establishment of the first graduate program specializing in human genetics. The first generation of students included Salamanca, who became a colleague and close friend, and Buentello (who later married Salamanca). This program was instrumental in developing the teaching of genetics at a time when human genetics was not taught at university level, and also brought Lisker's and Armendares's agendas closer together in the pursuit of a common goal, namely, the recognition of genetic factors in health and disease. For them, professional doctors required knowledge of the structure, function, mechanisms, and rules of gene transmission, while understanding the relationships between genes and the environment, thus fostering the development of medical genetics as a tool for answering biomedical as well as evolutionary questions.

Another important place where their agendas coincided, which also gave human genetics in Mexico its social life, was the creation of the AMGH. An initiative of 13 doctors, especially pediatricians, the AMGH was born on March 12, 1968, with a strong medical character. This association brought together specialists in this field to promote the training of human resources and the research and teaching of human genetics in Mexico. Among its founding members were Armendares, Lisker, and Salazar Mallén. In addition to these regular members, foreign, full, ascribed, and benefactor members were admitted. Salazar Mallén was the first president, in 1968, followed by Lisker, from 1969 to 1971, and Armendares, from 1971 to 1973 . The interdisciplinary nature of human genetics allowed the inclusion of specialists from other branches, such as biochemistry, biology, and chemistry.

With the creation of the AMGH, an important step was taken in the consolidation of human genetics in Mexico, whose principles at the beginning were: grouping professionals interested in the study of genetics, aiming to improve their knowledge for the benefit of the associates themselves and the community; establishing exchange with other scientific societies; and promoting teaching and research within the field of human genetics. ${ }^{22}$ Undoubtedly, the creation of the AMGH gave a considerable boost to the formation of interdisciplinary academic networks, and was an important forum for the discussion and dissemination of genetic knowledge. Also, it was a privileged site where the circulation of knowledge was facilitated: first, with the organization of theoretical and practical courses based at the UNAM Faculty of Medicine and attended by undergraduate and graduate students; second, with the planning and organization of touring national congresses that took place in November of each year with different themes and the participation of state universities and other medical organizations, with the clear purpose of disseminating 
genetic knowledge; and third, with the strengthening of academic ties between various national and international organizations, such as the Mexican Society of Pediatrics, the Mexican College of Gynecology and Obstetrics, the National Bioethics Commission, and the International Society of Prenatal Diagnosis.

Finally, due to the international collaborations and positioning of Mexican human geneticists, the Permanent Committee of the International Conferences of Human Genetics, headed by Neel, Armendares, F. Clarke Fraser, Jean de Grouchy, and Lionel Penrose, among others, decided to give Mexico the opportunity to host the meeting. The first congress had been held in 1956 in Copenhagen in an effort to bring together human geneticists from all over the globe to contribute in all aspects of human genetics, including clinical practice, research, and education, and to foster international networks of collaboration that allowed the circulation of people, methods, and practices.

The Mexican Organizing Committee included Salazar Mallén, Armendares, and Lisker. This congress was the first to be hosted by a Latin American country, and in its five-day duration, more than two hundred works on different aspects of human genetics were presented. It is worth noting that Mexican geneticists were at the time not only working at the Unit for Research in Human Genetics, but in other research institutions that were developing human genetics in clinical practice, such as the Pediatrics Hospital and the Mexican Children's Hospital, both in Mexico City, and others at different state institutions (Armendares, Lisker, 1977).

Although Armendares left CMN for the Anthropological Research Institute of UNAM in 1980 to set up a genetics laboratory, his collaboration with Lisker did not stop. ${ }^{23}$ They performed studies on certain polymorphisms and gene frequencies in some populations in Mexico and other cities (see, for example, Armendares et al., 1983; Lisker et al., 1986, 1994), and continued his collaboration in the expanding fields of bioethics and genetic counselling (on bioethics, see, for example, Armendares et al., 1985; Carnevale et al., 1998; on genetic counselling, see, for example, Carnevale et al., 1997). ${ }^{24}$ The bioethical dimension within medical genetics, instilled initially by a small number of key founders such as Lisker and Armendares, paved the way for new lines of research and medical practice.

\section{Final considerations}

The history of human genetics in Mexico is little explored by historians and poorly represented in the history of science and technology studies. However, some works are beginning to appear at the turn of the century which attempt to reconstruct, from a transnational perspective, the relationship of human genetics with the development of the modern Mexican state and the national and foreign institutions which arose as a result of World War II (see, for example, Cueto, 2007; Soto Laveaga, 2009; Wade, López Beltrán, Santos, 2014). This manuscript adds to our understanding of genetics in Mexico by demonstrating how the practices of cytogenetics and population genetics were combined intellectually and institutionally.

The development of human genetics in 1960s Mexico was mediated by the scientific practices that Armendares and Lisker had learned abroad, as they applied international 
standards to the Mexican setting. They were key elements in the construction of national scientific policies in the clinic to improve the healthcare system and tackle national priorities such as Down syndrome, and G6PD and lactase deficiencies, thus contributing to global knowledge of human biology. The distance between the laboratories and their field sites facilitated their efforts to connect both with the clinic at a moment when biomedicine was emerging as a post-World War II enterprise (Radin, 2017).

It would be pointless to acknowledge Armendares's and Lisker's contributions to human genetics without taking into account global concerns about the effects of nuclear radiation on human populations at the intersection of nuclear physics and genetics after Second World War, and also the need to deliver healthcare services and scientific knowledge to the general population. Armendares took part in the international project on congenital malformations, and Lisker was part of the international project on the characterization of human variability. For Lisker and his collaborators, the long-term effort to carry out research on indigenous populations in order to provide insights into the biological history of the human species, disease patterns, and biological relationships among populations was of particular interest. When put into the international Cold War context, Lisker's studies added to global knowledge on the geographical distribution of genetic markers.

Armendares's emphasis was on the population genetics of congenital illnesses and genetic disorders such as Down syndrome and malnutrition. His target was the child population. These studies were the first in Mexico in the 1960s, and were aligned with international projects for the characterization of different genetic-variant conditions. Armendares's studies began with a clinically affected child, central to the thinking and practices of post-war medical genetics, which strongly shaped conceptions about the genetic basis of chromosomal disorders (Hogan, 2016).

Research on human populations in Mexico was not only of anthropological importance, but also had clear medical applications: the design of medical policies specific to those populations experiencing higher rates of anemia and malaria (Barahona, 2016b). Mexican indigenous populations were experimental sites for producing health policies and standardized scientific and clinical practices, and also for testing hypotheses about the historical interactions between different populations, showing a clear intersection of the development of post-World War II biomedicine and the political project of postrevolutionary Mexico (see Cueto, 2007, 2015; for Armendares and post-revolutionary Mexico, see Barahona, 2015).

Although they had different backgrounds and trajectories, Armendares and Lisker shared a research and medical agenda, which was the improvement of the healthcare system based on reliable scientific knowledge, addressing global concerns about human genetics at the same time by focusing on human biology variability and health problems typical of the second half of the twentieth century. They adroitly managed collaborations and proved adept at building sites of cognition, assessing similarities and adapting techniques learned abroad.

They used the studied populations as laboratories for knowledge production: laboratories or sites where they mobilized cognitive as well as material resources to derive models to be applied on a larger scale (Santos, Lindee, Souza, 2014). Lisker set up temporary laboratories 
in the local towns where samples were taken and clinical exams were carried out. Then, he would travel back to his laboratory at the hospital with these samples to conduct the molecular analysis. The proximity of Armendares's laboratory to the hospital allowed him to take both as part of the same process of knowledge production. Child and indigenous populations played the same role, as laboratories for knowledge production and sites of cognition. As Radin has shown for frozen blood samples, the samples taken from child and indigenous populations became resources for biomedical science and allowed the field to be connected with the laboratory and the clinic (Radin, 2017).

The collaboration of Armendares at CMN and Lisker at the Nutrition Illnesses Hospital, combining cytogenetic studies with population genetics studies, shows the entangled histories of two different physicians with shared scientific agendas. Their collaboration and close friendship allowed them to have joint publications, to foster their mutual interests in the genetics of congenital and blood diseases, to work in the rising field of bioethics and genetic counselling, and, no less importantly, to foster and boost the social life of human genetics with the founding of the AMGH and the organization of national and international meetings and congresses. This association provided the infrastructure for human genetics, and had a significant presence in the field since its foundation in 1968: it was a central institution for laboratory and clinical workspaces and education, "in which researchers were focused on improving the diagnosis, understanding, treatment, and prevention of a specific disorder" (Hogan, 2016, p.XI).

I have attempted to show the complex interplay between biographical accident, tacit knowledge, institution building, and material culture in the production of knowledge. As we have seen, the careers of Mexican physicians-turned-geneticists and the practices and techniques they handled were the focus of this historical narrative, with an emphasis on the construction of child and indigenous populations as sites of knowledge inquiry. I have attempted to show that the knowledge and practices of cytogenetics and population genetics circulated during the 1960s and 1980s in Mexico in conjunction with journeys to and from different geographical places, allowing the construction of populations as laboratories for analytical scrutiny or sites of cognition, and also the development and institutionalization of human genetics in the country.

Both Armendares and Lisker, colleagues and friends, were as committed to the study of shared languages and practices in their respective fields and disciplines as they were to networks of international collaboration in order to guarantee local conditions for the establishment of human genetics in the country.

This manuscript contributes both theoretically and empirically to the history of science and technology by delving into two case studies that show the international process of the emerging model of human genetics after Second World War, where Mexican human geneticists were very active in learning about and adapting the new rising scientific practices of biomedicine across borders as part of the scientific networking typical of the post-war era.

I would like to thank Alicia Villela González, MSc, for her expert research assistance, David Bevis for his great effort in the correction of the language, José Antonio Alonso for the editing of the manuscript, 
and two anonymous reviewers whose comments improved the final version. This paper was supported by the Programa Universitario de Bioética, UNAM, and projects Conacyt Integra and DGAPA/PAPIIT IN 403718. The ideas presented in this manuscript were discussed in the session "Transnational knowledge during the Cold War: the case of the life and medical sciences" at the 25th International Congress of History of Science and Technology, held in July 2017 in Rio de Janeiro, Brazil, organized by Marcos Cueto and the author.

\section{NOTES}

${ }^{1}$ Historian of science Warwick Anderson (2012, p.231) draws upon "sites of cognition and critical reflection" to refer to how populations, travels, and clinical practices function as sites of scientific inquiry or sites for analytical scrutiny. I thank Susan Lindee for having sent me an unpublished version of the manuscript "Building site of cognition: shades of primitiveness in human biological diversity studies in Cold War Brazil (1962-1970)," co-authored by Santos, back in June 2014, when I was organizing the international colloquium on Human Genetics and Medicine during the Cold War held at the UNAM in May 2015, in which Lindee participated. In this manuscript the authors refer to Anderson's "sites of cognition" idea. The published title of the paper changed slightly (see Santos, Lindee, Souza, 2014).

${ }^{2}$ Problematizing populations began with the development of demography back in the eighteenth century, stimulating the creation of national policies for the state to intervene, thus creating "populations" as new objects of inquiry and knowledge production (see Lock, Nguyen, 2010; Bangham, 2014).

${ }^{3}$ Flows of samples and information are co-produced in activities rather than things (Hoeyer, Tupasela, Rasmussen, 2017). Thus, diagnostic, treatment, and research activities are intertwined, and have to take place in the science network in order for them to travel (Anderson, 2008). Samples and information journeys across borders "remain attached to the hopes and concerns through which they were first produced" (Hoyer, Tupasela, Rasmussen, 2017, p.392).

${ }^{4}$ Recent historiographical studies have shown the complexity, and in many cases overlapping, of the terms "national," "international," or "global" and "transnational." According to Cueto and colleagues, "national" is understood to be that which constrains the nation as a unit, "global" is that which transcends nations, and "transnational" is that which transcends the nation without implying a global scope (Brown, Cueto, Fee, 2006).

${ }^{5}$ The Diego blood group or antigen system is composed of 21 antigens inherited through various alleles of a gene located in human chromosome 17. Some of these antigens can cause the hemolytic disease of the newborn.

${ }^{6}$ Weiner was internationally recognized for his studies on immunogenetics and serology, and was the pioneer in the discovery of the Rh factor in 1937 (Weiner, 1954).

${ }^{7}$ Motulsky is known as the father of pharmacogenetics. See Motulsky (1957).

${ }^{8}$ This department was renamed the Rubén Lisker Genetics Department in 2007. See Barahona (2009).

${ }^{9}$ Lisker personal communication on April 7 and 14, 2008.

${ }^{10}$ Genetic markers have been used to study the correlation between an inherited disease and its genetic cause since the early twentieth century. According to Hogan (2016, p.44), "the identification of a genetic marker for a disorder often brought about the recognition of new bodily characteristics and facilitated the diagnosis of patients with more variable clinical expressions... The introduction of a genetic marker reshaped expectations about the disorder's life history and patterns of malformation."

${ }^{11}$ Lisker, personal communication on April 7 and 14, 2008. See also, Swadesh (1959). In Barahona (2009, 2016a), Lisker's remembrances are recalled from an interview in 2008: "I remember that I consulted him (Swadesh): who am I studying? How do I do it? ... He provided me with his publications and informed me that at that time there were five large national linguistic groups and that each of them, except the Tarasco, had subdivisions with different geographical distributions. Thus, I learned their main characteristics and supported the National Indigenous Institute and the Ministry of Public Education in their study...Then, I studied genetic markers in indigenous and mestizo populations from the Mexican Republic" (Pérez-Tamayo, 2008, p.203; Barahona, 2009, p.104; Barahona, 2016a, p.15; see also Lisker, 1963, p.292). This statement contradicts what other historians of science preach as their own discovery in the history of population genetics in Mexico. 
${ }^{12}$ For his association with Baruch Blumberg on "albumin Mexico," see Melartin, Blumberg, Lisker (1967). This collaboration was part of Blumberg's agenda on the genetic characterization of human populations using serum albumin as a genetic marker. See Barahona (2016a).

${ }_{13}$ Another study also suggested that a pair of genes were what determined the levels of lactase in the intestine (Lisker, 1984).

${ }^{14}$ I agree with Reardon: the use of the word "race" to describe human population variability has not been the same since the nineteenth century to post-WWII period. By the 1950s, many scientists critiqued the notion of race based only on visible characteristics and recognized the need to replace it with a biological gene-based concept (Reardon, 2005).

${ }^{15}$ Barahona's 2009 book opened an original line of research in the history of human genetics (population genetics, cytogenetics, and radiobiology) in Mexico during the Cold War. After its publication, the erstwhile bachelor, MSc, and PhD student Edna Suárez and the author embarked on a collaboration which resulted in three joint manuscripts (Suárez, Barahona, 2011, 2013; Barahona, Suárez, 2011), where we depicted Lisker's contribution to medical and anthropological genetics and blood diseases in greater detail.

${ }^{16}$ Or as Santesmases (2017) has put it, a diagnostic exercise.

${ }^{17}$ Frenk personal communication of November 26, 2012, and November 14, 2017.

${ }^{18}$ Armendares personal communication of March 20 and 28, 2008; Barahona (2015).

${ }^{19}$ It is worth noting that Armendares learnt this technique in his training at Oxford and was of basic use at the Unit. It is described in Armendares, Urrusti, Ramírez (1968). See also, De Chadarevian (2013).

${ }^{20}$ Lisker personal communication of May 6, 2015. Lisker was supposed to attend the colloquium I organized in May 2015, but could not do so due to an illness that kept him away from his laboratory. He had retired to his home a few months before, only receiving his close colleagues and friends.

${ }^{21}$ Armendares personal communication of May 19, 2008. After Lisker left the program in the 1990s, José Antonio Velázquez took over responsibility for teaching the Human Population Genetics course, as it is called now (Lisker personal communication of November 24, 2012). It is worth noticing that Velázquez studied under Neel's supervision at Michigan University. As Neel was in Japan for his first year there, he studied the genetics of somatic cells with Robert Krooth in the same department. Velázquez is well known for the introduction of the prenatal screening program to Mexico. Velázquez personal communication of November 14, 2017.

${ }^{22}$ It is worth mentioning that other groups or societies that subsequently appeared as the Nucleus of Studies in Health and Law of the Institute of Legal Research of UNAM in 1992, and the Mexican Society of Genomic Medicine in 2003, took their fundamental principles from AMGH.

${ }^{23}$ Buentello resigned from the Unit for Research in Human Genetics to move with Armendares to UNAM. She worked there until Armendares's death in 2010. Buentello personal communication of November 9, 2012.

${ }^{24}$ It is worth noting that Lisker was part of the WHO Working Group on Genetic Counselling as the Mexican representative, and gave Armendares advice on the subject. See WHO (1969) and Barahona (2017).

\section{REFERENCES}

ANDERSON, Warwick.

Hybridity, race, and science: the voyage of the Zaca, 1934-1935. Isis, v.103, p.229-253. 2012.

ANDERSON, Warwick.

The collectors of lost souls: turning Kuru scientists into whitemen. Baltimore: The John Hopkins University Press. 2008.

ARMENDARES, Salvador; BUENTELLO Leonor; FRENK; Silvestre.

Two male sibs with uterus and fallopian tubes: a rare, probably inherited disorder. Clinical Genetics, v.4, n.3, p.291-296. 1973.
ARMENDARES, Salvador; BUENTELLO, Leonor; SALAMANCA, Fabio.

Case report: an extra small metacentric autosome in a mentally retarded boy with multiple malformations. Journal of Medical Genetics, v.8, n.3, p.378-380. 1971.

ARMENDARES, Salvador; LISKER, Rubén (Ed.). Human genetics. Oxford: Excerpta Medica. 1977.

ARMENDARES, Salvador; SALAMANCA, Fabio; FRENK, Silvestre.

Estado actual de los conocimientos del efecto de la desnutrición sobre el material genético. Gaceta Médica de México, v.107, p.367-376. 1974. 
ARMENDARES, Salvador; SALAMANCA, Fabio; FRENK, Silvestre.

Chromosome abnormalities in severe protein calorie malnutrition. Nature, v.232, p.271-273. 1971.

ARMENDARES, Salvador; URRUSTI, Juan; RAMÍREZ, G.

Citogenética humana, normal y patológica. México, D.F.: Interamericana. 1968.

ARMENDARES, Salvador et al.

Sensibilidad de seis marcadores genéticos para la identificación de ilegitimidad en la Ciudad de México. Revista de Investigación Clínica, v.37, n.1, p.27-30. 1985.

ARMENDARES, Salvador et al.

Absence of correlation between Y chromosome heterochromatin and several anthropometric measurements in a Mexican population. Human Genetics, v.63, n.3, p.283-284. 1983.

ARTEAGA, C. et al.

Blood agglutinogens of Mexicans. Annals of Eugenics, v.16, n.1, p.351-358. 1952.

BANGHAM, Jenny.

Blood groups and human groups: collecting and calibrating genetic data after World War II. Studies in History and Philosophy of Biological and Biomedical Sciences, v.47, p.74-86. 2014.

BARAHONA, Ana.

Local, global and transnational perspective on the history of biology. In: Dietrich, Michael; Borrello, Mark; Harman, Oren (Ed.). Handbook of the historiography of biology. Cham: Springer. p.229-250. 2018.

BARAHONA, Ana.

Karyotyping and genetic counselling in Mexico in the 1960s. In: Peterman, Heike I.; Harper, Peter, S.; Doetz, Susanne (Ed.). History of human genetics. Cham: Springer. p.485-502. 2017.

BARAHONA, Ana.

Medical genetics and the first studies of the genetics of populations in Mexico. Genetics, v.204, n.1, p.11-19. 2016 a.

BARAHONA, Ana.

Population studies and genetics in Mexico during the Cold War. In: Beezley, William (Ed.). The Oxford research encyclopedia of Latin American history. New York: Oxford University Press. 2016b.

BARAHONA, Ana.

Medical genetics in Mexico: the origins of cytogenetics and the health care system. Historical Studies in the Natural Sciences, v.45, n.1, p.147-173. 2015.
BARAHONA, Ana.

Historia de la genética humana en México, 1870-1970. Ciudad de México: Las Prensas de Ciencias; Unam. 2009.

BARAHONA, Ana; SÚAREZ, Edna. Moléculas y evolución: el estudio de grupos humanos en México, 1945-1967. In: Muñoz Rubio, J. (Coord.). La evolución humana: biología, política, racismo. México, D.F.: CEICH; UNAM. p.195-218. 2011.

BOWMAN, James E. et al.

Genetics of starch-gel electrophoretic variants of human 6-phosphogluconic dehydrogenase: population and family studies in the United States and Mexico. Nature, v.210, n.5038, p.811813. 1966.

BROWN, Theodore M.; CUETO, Marcos; FEE, Elizabeth.

The World Health Organization and the transition from "international" to "global" public health. American Journal of Public Health, v.96, n.1, p.62-72. 2006.

CARNEVALE, Alessandra et al.

Attitudes of Mexican geneticists towards prenatal diagnosis and selective abortion. American Journal of Medical Genetics, v.75, n.4, p.426-431. 1998.

CARNEVALE, Alessandra et al.

Counselling following diagnosis of a fetal abnormality: comparison of different clinical specialists in Mexico. American Journal of Medical Genetics, v.69, n.1, p.23-28. 1997.

CARSON, Paul E. et al.

Enzymatic deficiency in primaquine-sensitive erythrocytes. Science, v.124, n.3220, p.484-485. 1956.

COMFORT, Nathaniel.

The science of human perfection. New Haven: Yale University Press. 2012.

CUETO, Marcos.

An asymmetrical network: national and international dimensions of the development of Mexican physiology. Journal of the History of Medicine and Allied Sciences, v.71, n.1, p.43-63. 2015.

CUETO, Marcos.

Cold war, deadly fevers: malaria eradication in Mexico, 1955-1975. Baltimore: Johns Hopkins University Press. 2007.

DE CHADAREVIAN, Soraya.

Chromosome photography and the human karyotype. Historical Studies in the Natural Sciences, v.45, n.1, p.115-146. 2015. 
DE CHADAREVIAN, Soraya.

Chromosome surveys of human populations: between epidemiology and anthropology. Studies in History and Philosophy of Biological and Biomedical Sciences, v.47, p.87-96. 2014.

DE CHADAREVIAN, Soraya.

Putting human genetics on a solid basis: human chromosome research, 1950-1970. In: Gausemeier, Bernd; Müller-Wille, Staffan; Ramsden, Edmund (Ed.). Human heredity in the twentieth century. London: Pickering and Chatto. p.141-52. 2013.

FIALKOW, Philip J. et al.

6PGD: homozygous manifestation in a patient with leukemia. Science, v.163, p.194-195. 1969.

FRENK, Silvestre et al.

Experimental nephrotic syndrome induced in rats by aminonucleoside: renal lesions and body electrolyte composition. Experimental Biology and Medicine, v.89, n.3, p.424-427. 1955.

HA, Nathan Q.

Diagnosing sex chromatin: a binary for every cell. Historical Studies in the Natural Sciences, v.45, n.1, p.49-84. 2015.

HACKING, Ian.

Making up people. In: Heller, Thomas; Sosna, Morton; Wellbery, David (Ed.). Reconstructing individualism: autonomy, individuality, and the self in western thought. Stanford: Stanford University Press. p.222-236. 1986.

HARPER, Peter, S.

Human genetics in troubled times and places. Hereditas, v.155, n.7, p.1-14. 2018.

HOEYER, Klaus; TUPASELA, Aaro; RASMUSSEN, Malene B.

Ethics policies and ethics work in cross-national genetic research and data sharing: flows,

nonflows, and overflows. Science, Technology, and Human Values, v.42, n.3, p.381-404. 2017.

HOGAN, Andrew J.

Life histories of genetic disease. Baltimore: Johns Hopkins University Press. 2016.

LINDEE, Susan.

Human genetics after the bomb: archives, clinic, proving grounds and board rooms. Studies in History and Philosophy of Biological and Biomedical Sciences, v.55, p.45-53. 2015.

LINDEE, Susan.

Scaling up: human genetics as a Cold War network. Studies in History and Philosophy of Biological and Biomedical Sciences, v.47, p.185-190. 2014.

LINDEE, Susan

Moments of truth in genetic medicine. Baltimore: Johns Hopkins University Press. 2005.
LINDEE, Susan.

Suffering made real. Chicago: The University of Chicago Press. 1994.

LISKER, Rubén.

Lactase deficiency. In: Bourges, Héctor; Velázquez, Antonio (Comp.). Genetic factors in nutrition. New York: Academica. p.93-103. 1984.

LISKER, Rubén.

Estructura genética de la población mexicana:

aspectos médicos y antropológicos. México: Salvat Mexicana. 1981.

LISKER, Rubén.

Estudios sobre algunas características hematológicas hereditarias de la población mexicana: II hemoglobinas anormales en 7 grupos indígenas y algunos mestizos. Gaceta Médica de México, v.93, n.4, p.289-297. 1963.

LISKER, Rubén; AGUILAR, Lydia; ZAVALA, Carlos.

Intestinal lactase deficiency and milk drinking capacity in the adult. The American Journal of Clinical Nutrition, v.31, n.9, p.1499-1503. 1978.

LISKER, Rubén, GONZÁLEZ, Beatriz, DALTABUIT, Magali.

Recessive inheritance of the adult type of intestinal lactase deficiency. American Journal of Human Genetics, v.27, n.5, p.662-664. 1975.

LISKER, Rubén; LORIA, Alvar; CÓRDOVA, Soledad.

Studies on several hematological traits of the Mexican population, VIII: hemoglobin S, glucose-6-phosphate dehydrogenase deficiency and other characteristics in a malarial region. American Journal of Human Genetics, v.17, n.2, p.179-187. 1965.

LISKER, Rubén; PÉREZ-BRICEÑO, Rocío; BEUTLER, Ernest.

A new glucos-6-phosphate dehydrogenase variant, GD(-) Tepic, characterized by moderate deficiency and mild episodes of hemolytic anemia. Human Genetics, v.69, n.1, p.19-21. 1985

LISKER, Rubén; ZÁRATE, Graciela; LORIA, Alvar.

Studies on several genetic hematological traits of Mexicans, IX: abnormal hemoglobins and erythrocytic glucose-6-phosphate dehydrogenase deficiency in several Indian tribes. Blood, v.27, n.6, p.824-830. 1966.

LISKER, Rubén et al.

Red cell acid phosphatase types and GC polymorphisms in Mérida, Oaxaca, León, and Saltillo, Mexico. Human Biology, v.66, n.6, p.1103-1109. 1994. 
LISKER, Rubén et al.

Gene frequencies and admixture estimates in a Mexico City population. American Journal of Physical Anthropology, v.71, n.2, p.203-207. 1986.

LISKER, Rubén et al.

Lactase deficiency in a rural area of Mexico. American Journal of Clinical Nutrition, v.27, n.7, p.756-759. 1974.

LISKER, Rubén et al.

Glucose-6-phosphate dehydrogenase: Mexico, a new variant with enzyme deficiency, abnormal motility and absence of hemolysis. Journal of Laboratory and Clinical Medicine, v.79, n.5, p.788793. 1972.

LISKER, Rubén et al.

6-Phosphogluconate dehydrogenase (6PGD) in Down syndrome. Clinical Genetics, v.2, n.4, p.210-213. 1971.

LISKER, Rubén et al.

Note préliminaire sur la fréquence des hemoglobines anormales et de la déficience en glucose-6-phosphate déhydrogénase dans la population Mexicaine. Revue Française d'Etudes Cliniques et Biologiques, v.7, n.1, p.76-78. 1962.

LOCK, Margaret; NGUYEN, Vinh-Kim. An anthropology of biomedicine. Oxford: WileyBlackwell. 2010.

MACLEOD, Roy; REHBOCK, Philip. Darwin's laboratory: evolutionary theory and natural history in the Pacific. Honolulu: University of Hawaii Press. 1994.

MELARTIN, Lissa; BLUMBERG, Baruch S.; LISKER, Rubén.

Albumin Mexico, a new variant of serum albumin. Nature, v.215, p.1288-1289. 1967.

METCOFF, Jack et al.

Intracellular composition and homeostatic mechanisms in severe chronic infantile malnutrition. Pediatrics, v.20, n.2, p.317-336. 1957.

MOORHEAD, Paul Sidney et al. Chromosome preparations of leukocytes cultured from human peripheral blood. Experimental Cell Research, v.20, n.3, p.613-616. 1960.

MOTULSKY, Arno G.

Drug reactions, enzymes, and biochemical genetics. Journal of the American Medical Association, v.165, n.7, p.835-837. 1957.

MOTULSKY, Arno G.; CAMPBELL-KRAUT, Jean. Population genetics of G6PD deficiency of the red cell. In: Blumberg, Baruch (Ed.). Genetic polymorphisms and geographic variation in disease. New York: Grune and Stratton. 1961.
MUTCHINICK, Oswaldo et al.

Frequency of sister chromatid exchange in severe protein malnutrition. Annals de Génétique, v.22, n.3, p.129-132. 1979.

PANTELAKIS, Stefanos N. et al.

Red cell enzymes in trisomy 21. American Journal of Human Genetics, v.22, n.2, p.184-193. 1970.

PÉREZ-TAMAYO, Ruy.

Rubén Lisker. In: Pérez-Tamayo, Ruy (Coord.). Médicos mexicanos, siglo $X X$. México: Universidad de Colima. p.104-105. 2008.

RADIN, Joanna.

Life on ice: a history of new uses for cold blood. Chicago: The University of Chicago Press. 2017.

REARDON, Jenny.

Race to the finish. New Jersey: Princeton

University Press. 2005.

RODRÍGUEZ, Héctor et al.

Studies on several genetic hematological traits of the Mexican population, V: distribution of blood groups antigens in Nahuas, Yaquis, Tarahumaras, Tarascos and Mixtecos. Human Biology, v.35, n.3, p.350-360. 1963.

ROSADO, Jorge L. et al.

Enzyme replacement therapy for primary adult lactase deficiency. Gastroenterology, v.87, n.5, p.1072-1082. 1984.

SALAMANCA, Fabio; BUENTELLO, Leonor; ARMENDARES, Salvador.

Ring D1 chromosome with remarkable morphological variation in a boy with mental retardation. Annals de Génétique, v.15, n.3, p.183186. 1972.

SALAZAR MALLÉN, Mario.

El aglutinógeno Lewis en la sangre de los mexicanos. Boletín del Instituto de Estudios Médicos y Biológicos, v.7, p.25-30. 1949.

SALAZAR MALLÉN, Mario; ARIAS, Teresa. Inheritance of Diego blood group in Mexican Indians. Science, v.130, n.3368, p.164-165. 1959.

SALAZAR MALLÉN, Mario; HERNÁNDEZ DE LA PORTILLA, Raúl.

Existencia del aglutinógeno Rh en los hematíes de 250 individuos Mexicanos. Revista de la Sociedad Mexicana de Historia Natural, v.5, p.183185. 1944.

SANTESMASES, María Jesús.

Circulating biomedical images: bodies and chromosomes in the post-eugenic era. History of Science, v.55, n.4, p.395-430. 2017.

SANTESMASES, María Jesús. Human chromosomes and cancer: tumors and the geographies of cytogenetic practices, 1951- 
1956. Historical Studies in the Natural Sciences, v.45, n.1, p.85-114. 2015.

SANTESMASES, María Jesús.

The autonomous karyotype and the origins of prenatal testing: children, pregnant women and early down syndrome cytogenetics, Madrid 1962-1975. Studies in History and Philosophy of Biological and Biomedical Sciences, v.47, p.142-153. 2014.

SANTOS, Ricardo Ventura; LINDEE, Susan; SOUZA, Vanderlei de.

Varieties of the primitive: human biological diversity studies in Cold War Brazil (1962-1970). American Anthropologist, v.116, n.4, p.723-735. 2014.

SOTO LAVEAGA, Gabriela.

Jungle laboratories: Mexican peasants, national projects, and the making of the pill. Durham: Duke University Press. 2009.

STERN, Alexandra Minna.

Telling genes: the story of genetic counseling in America. Baltimore: Johns Hopkins University Press. 2012.

STEVENSON, Alan C. et al.

Congenital malformations: a report of a study of series of consecutive births in 24 centers. Bulletin of the World Health Organization, v.34, suppl., p.9-127. 1966.

SÚAREZ, Edna; BARAHONA, Ana.

Postwar and postrevolution: medical genetics and social anthropology in Mexico (1945-1970). In: Müller-Wille, Stafan; Gausemeier, Bern;
Ramsden, Edmund (Ed.). Human heredity in the twentieth century. London: Pickering and Chatto. p.101-112. 2013.

SÚAREZ, Edna; BARAHONA, Ana.

La nueva ciencia de la nación mestiza: sangre y genética humana en la posrevolución mexicana. In: López Beltrán, Carlos (Coord.). Genes y mestizos: genómica y raza en la biomedicina mexicana. México: Ficticia. p.65-96. 2011.

SWADESH, Morris.

Indian linguistic groups of Mexico. México: Escuela Nacional de Antropología e Historia. 1959.

TURCHETTI, Simone; HERRÁN, Néstor; BOUDIA, Soraya.

Introduction: have we ever been

"transnational?" Towards a history of science across and beyond borders. British Journal of History of Science, v.45, n.3, p.319-336. 2012.

WADE, Peter; LÓPEZ BELTRÁN, Carlos;

SANTOS, Ricardo Ventura (Ed.).

Mestizo genomics: race, mixture, nation, and science in Latin America. London: Duke University Press. 2014.

WHO.

World Health Organization. Genetic counselling. Geneva: WHO (WHO technical report series, n.416). 1969.

WIENER, Alexander. $\mathrm{Rh}$-Hr blood types: applications in clinical and legal medicine and anthropology. New York: Grune and Stratton. 1954. 